Stergios Skaperdas

\title{
Restraining the Genuine Homo Economicus: \\ Why the Economy cannot be Divorced from \\ its Governance
}

University of California, Irvine

SP || 2003-03

May 2003

ISSN Nr. $0722-6748$

Research Area

Markets and Political Economy

Research Unit

Market Processes and Governance
Forschungsschwerpunkt

Markt und politische Ökonomie

Abteilung

Marktprozesse und Steuerung 
Zitierweise/Citation:

Stergios Skaperdas, Restraining the Genuine Homo

Economicus: Why the Economy cannot be Divorced

from its Governance, Discussion Paper SP || 2003 - 03,

Wissenschaftszentrum Berlin, 2003.

Wissenschaftszentrum Berlin für Sozialforschung gGmbH,

Reichpietschufer 50, 10785 Berlin, Germany, Tel. (030) 25491 - 0

Internet: www.wz-berlin.de 


\title{
ABSTRACT \\ Restraining the Genuine Homo Economicus: \\ Why the Economy cannot be Divorced from its Governance
}

\author{
by Stergios Skaperdas *
}

The Homo economicus of traditional economics is far from being completely self-interested, rational, or as individualistic as he is purported to be; he will haggle to death over price but will not take what he wants by force. Implicitly, he is assumed to behave ruthlessly within a well-defined bubble of sainthood. Based on a simple model, I first examine what occurs when this assumption is relaxed and genuine, amoral Homines economici interact. Productivity can be inversely related to compensation; a longer shadow of the future can intensify conflict; and, more competition among providers of protection reduces welfare. The patently inefficient outcomes that follow call for restraining self-interest, for finding ways to govern markets. I then review some of the different ways of creating restraints, from the traditional social contract, to the hierarchical domination of kings and lords, to modern forms of governance. Checks and balances, wider representation, the bureaucratic form of organization, and other ingredients of modern governance can partly be thought of as providing restraints to the dark side of self-interest. Though highly imperfect, these restraints are better than the alternative, which typically involves autocratic, amateurish, and corrupt rule. Then, thinking of most problems in terms of a first-best economic model is practically and scientifically misguided.

Keywords: Conflict, property rights, governance

JEL Classification: D7, H1

* Prepared for the Mancur Olson Memorial Seminar Series, University of Maryland, College Park, February 8, 2002. For comments I would like to thank seminar participants, Sam Bowles, Costas Lapavitsas, John McLaren, Joe Oppenheimer, Athanasios Orphanides, Piotr, Swistak, Jim Robinson, John Wallis, and participants at UC Davis' Economy, Justice, and Society seminar and at the Polarization and Conflict workshop in Barcelona. I gratefully acknowledge support from a grant for Research and Writing from the John D. and Catherine T. MacArthur Foundation. 


\section{Die Beschränkung des genuinen Homo Economicus: Warum wirtschaftliche Prozesse und Governancestrukturen untrennbar sind}

Der Homo Economicus der klassischen Wirtschaftswissenschaften ist dadurch gekennzeichnet, dass er zwar bis in den Tod um Preise feilscht, sich aber niemals Dinge mit Gewalt aneignen würde. So betrachtet ist er nicht in jeder Hinsicht vollständig eigennützig und rational oder individualistisch. Diese Eigenschaften treffen nur auf eine Dimension seines Verhaltens zu, nämlich auf sein Verhalten im Marktgeschehen. In Hinblick auf das Respektieren von Eigentumsrechten verhält sich der Homo Economicus geradezu wie ein Heiliger. Basierend auf einer einfachen Analyse wird in der Arbeit untersucht, welche Konsequenzen die Lockerung dieser Annahme hat. Die Interaktion solcher nunmehr wirklich eigennütziger Homines Economici hat verschiedene Implikationen. Beispielsweise kann eine besonders hohe Produktivität eines Akteurs dazu führen, dass er eine besonders niedrige Entlohnung erhält. Auch kann die Möglichkeit zukünftiger Verhandlungen Konflikte in der Gegenwart verschärfen. Ferner wird ein stärkerer Wettbewerb zwischen Akteuren, die den Schutz von Eigentumsrechten anderer als Dienstleistung anbieten, die Wohlfahrt senken. Solche Ineffizienzen können dazu führen, dass es allokationspolitisch sinnvoll ist, den Eigennutz zu zügeln und Märkte zu regulieren. In der Arbeit werden verschiedene Möglichkeiten geprüft, solche Beschränkungen zu schaffen, vom traditionellen Gesellschaftsvertrag über die hierarchische Herrschaft von Königen und Adligen, bis hin zu modernen Regierungsformen. Checks and Balances, die umfassende Repräsentation, die bürokratische Organisationsform und andere Elemente des modernen Regierens können teilweise für Beschränkungen der "dunklen Seite" des Eigennutzes sorgen. Obwohl solche Formen der Beschränkung nicht sehr wirkungsvoll sind, sind sie gegenüber ihren Alternativen überlegen, die typischerweise mit autokratischer, amateurhafter und korrupter Herrschaft einhergehen. 


\section{Introduction}

For at least a century economists have persistently tried to divorce the study of the economy from the study of its governance. Initially, the sharp division - signified by renaming "political economy" into the more scientific-sounding "economics" - was undertaken just for analytical purposes. The world is complicated, it was argued, and by separating the economic from the political and the social we can analyze it better. Someone of course would have to put things together, but it was unclear who would. In the end, it is political scientists, sociologists, and public policy analysts who have been considering the interaction between the economic and the political. For long stretches of economic thought in the meantime, interventions in the economy could only be represented as distortions of an otherwise efficient economic Nirvana.

Dissenting voices of course were always there. More recently those of North (1990) and Olson $(1996,2000)$ have been prominent ones, and the recent experience of post-Soviet states in acquiring free-wheeling mafias instead of free markets provides prima facie evidence of the difficulties in separating economics from politics. However, even the strongest evidence will have difficulty dislodging prevailing theories and approaches unless it is replaced by theories that can subsume the existing ones. ${ }^{1}$ Whereas no such general theory exists at the moment, there is a body of research within economics developed over that past decade or so that holds promise and on which this paper is based.

I will first argue that self-interested behavior has a dark side that needs to be controlled for successful economic performance to take place. This point is perhaps too obvious to even be made for most readers, yet it has been assumed away in both modeling and empirical research in much of economics and therefore it needs to be emphasized and expressed in the modeling language of modern economics. Human beings do not just make a living by producing; they can also engage in non-productive activities that appropri-

\footnotetext{
${ }^{1}$ While reading Mancur Olson's last book (Olson, 2000), I was continually thinking about the possible reactions of my perhaps less sympathetic colleagues. As laymen they would tend to agree with most individual points, but as economists they would have difficulty fitting the pieces within the economic framework they are accustomed to. Ultimately, they would feel uncomfortable about the wholesale revision that evidently the received approach would require. That the assumption of unrestrained self-interest logically leads to the need to consider economics as not separate from politics was also argued by Bowles and Gintis (1993).
} 
ate the production of others. Employees within organizations spend time influencing their bosses instead of working; managers of corporations can enrich themselves instead of promoting the interests of their supposed bosses, the shareholders, stakeholders, or voters; individuals and firms lobby for subsidies, reduced taxes, and favorable legislation; and, individual, groups, and countries arm themselves to defend or take away the production of others. When these appropriative activities are taken into account within an economic model, in addition to the loss of efficiency, the distributional outcomes are very different from those that would emerge when appropriation is not considered. Instead of the more productive receiving higher compensation, they can receive less than the less productive who have an advantage in appropriation. Then, the incentives for innovation and productive capital accumulation would also be very different when appropriation is considered.

Although appropriation cannot be completely eliminated, how it is managed has dramatic economic consequences. Appropriation occurs in war of all against all, in despotic and highly extractive rule, and in modern national states in which the contests formerly taking place in the battlefield are now taking place in the political arena and the courts, but obviously its effects in these three environments are very different. I therefore next review some of the ways the dark side of self interest can be constrained. ${ }^{2}$

The response that has received much attention in economics and rationalchoice social science over the past two decades is based on the "folk theorem" and the importance of the "shadow of the future." I argue that the understanding that can come from this approach has been overrated. The underlying equilibria are non-robust, a longer shadow of the future in conflict situations can actually make things worse, and typically applications of the approach essentially abstract from the particular institutions that they study.

The provision of security and protection against the most egregious examples of appropriation has been the main ingredient in many definitions of the state. I consider then how precisely can the state provide restraints against appropriation. One candidate state is the autocratic or proprietary one, headed by a ruler with few restraints in his power, a "stationary bandit," to use Mancur Olson's evocative term (Olson, 1991). In reviewing the small

\footnotetext{
${ }^{2}$ I do not touch upon the recent literature on social capital (see, eg, Putnam, 2000) which argues for the importance of social restraints on the the dark side of self-interest. What examine is the relevance of governance, of the importance of political restraints.
} 
economics literature on the subject, however, I conclude that the conditions under which an autocratic ruler with a vested interest in severely reducing appropriation is limited. For a ruler is a big bandit who has correspondingly higher extractive powers than small-time bandits have. The control of the appropriative powers of autocratic rulers, then, can be a bigger problem than the control of simple banditry and robbery. It is under those conditions that government can be said to become the problem and not the solution.

Modern governance, however, with the patchwork of checks and balances, wider representation, professional bureaucracies, and loyalty to national states has managed, I argue, to overcome some of the most damaging aspects of appropriation and conflict. Fighting in the battlefield has been supplanted in most cases by fighting in courts and the halls of parliament. Appropriation has taken new forms and does not imply anything close to Nirvana efficiency, but that is not the relevant measure of comparison. The arbitrary and amateurish governance of absolutism that has prevailed for almost all of history and which still prevails in much of the globe is the more appropriate measure of comparison. For the most pressing problems in developing and transitioning economies as well as for many economic questions in the industrialized world, I conclude that it would be scientifically misguided to assume a world free of the appropriative activities that are examined here.

\section{On the Received Approach}

To illustrate the basic problem I begin with the simple textbook model of exchange. Consider two individuals - call then Robinson $(R)$ and Xena $(X)$ - who value two material goods, say fish $(f)$ and coconuts $(c)$. Suppose Robinson holds an endowment $e_{R}$ that can only be converted one-for-one into fish, whereas Xena holds an endowment $e_{X}$ that she can similarly convert one-to-one into coconuts. ${ }^{3}$ Consumption $f_{i}$ of fish and $c_{i}$ of coconuts by $i=R, X$ induces utility $U\left(f_{i}, c_{i}\right)$, which, for reasons of exposition later, we assume to be linearly homogeneous.

One of the fundamental problems of modern economics, first formulated in a familiar form by Edgeworth (1881), is the problem of exchange between the likes of Robinson and Xena. What is the most reasonable process by

\footnotetext{
${ }^{3}$ The complete specialization assumed here could be derived from the Ricardian model of trade whereby the two individuals can produce both goods but they endogenously choose to specialize, one in the production of fish and the other in the production of coconuts.
} 
which the two sides will arrive at an exchange of some of Robinson's fish for some of Xena's coconuts? What determines these exchange ratios or prices? Are there conditions under which prices will be close to those that would prevail under perfect competition? Much brainpower has been expended on such questions over more than a century, with some questions being more important than others at different times. ${ }^{4}$

Regardless of the approach taken in this setting, however, there is a tendency for outcomes to have the property that goods that are more valued to have higher prices, and those who hold such goods to receive higher incomes and utility. For instance, under competitive pricing, the final utility received by Robinson can be shown to equal $e_{R} \frac{\partial U\left(e_{R}, e_{X}\right)}{\partial f}$ and the utility received by Xena is $e_{X} \frac{\partial U\left(e_{R}, e_{X}\right)}{\partial c}$. Suppose $e_{R}=e_{X}=E$. Then, the person who would receive higher utility would also be Robinson if and only if $\frac{\partial U(E, E)}{\partial f}>\frac{\partial U(E, E)}{\partial c}$. That is the person who, other things being equal, holds the endowment that contributes higher marginal utility also would receive higher compensation. Moreover, such a property does not hold just for the case of exchange and utility. The simple problem of exchange we are discussing is analytically isomorphic to the basic problem of production, whereby the endowments of Robinson and Xena are inputs used in the production of a final consumption good by a means of a production function that has the same properties that the utility function has. Under such a production interpretation of the model, the more marginally productive person would have a higher wage rate and, other things equal, would also receive higher utility. ${ }^{5}$

There's a caveat, however, to the whole approach. What would prevent Xena - who is a warrior princess - from just using some coconuts to bang Robinson's head and take away all the fish from him? Then, if Robinson were to take that into consideration, he would have to take appropriate countermeasures by shifting his production to defensive goods or other goods that are less easily appropriable by Xena. The caveat is too obvious and has

\footnotetext{
${ }^{4}$ For example, the study of the bargaining problem was virtually abandoned between the 1950s and the early 1980s, when Rubinstein's (1982) approach along with developments in game theory revived interest in the problem. During the intervening years, implicitly if not explicitly trading at competitive equilibrium prices was the standard assumption both in modeling and empirical research.

${ }^{5}$ With more general utility and production functions or with different ways of determining exchange, defining contribution to marginal utility or productivity are not as clear cut, but we would be hard pressed to find cases in which those who contribute more to utlity or more to production receive less compensation.
} 
been too important historically, and continues to be important today, for Edgeworth to have ignored it as the following statement shows:

The first principle of economics is that every agent is actuated only by self-interest. The workings of this principle may be viewed under two aspects, according as the agent acts without or with, the consent of others affected by his actions. In wide senses, the first species of action may be called war; the second, contract.

Edgeworth (1881, pp.16,17)

Though perhaps "war" in this quote appears to be of a rather benign nature, still Edgeworth did not pursue the matter further. Subsequent authors did not even feel the need to introduce a caveat or acknowledge the assumption of near-sainthood of the homo economicus of modern economics. A notable exception was Haavelmo (1954) who introduced a framework that allows for both production and appropriation, and discussed implications of such a setting for economic development. Haavelmo's work in this area was almost completely ignored, though he received the Nobel prize for his research in econometrics. ${ }^{6}$ It is only recently that the big caveat has been reintroduced, to which we now turn.

\section{Robinson versus Xena}

To allow for the possibility of grabbing and defending, suppose that Robinson and Xena can allocate part of their endowment to arming so that

$$
\begin{aligned}
& e_{R}=f+g_{R} \\
& e_{X}=c+g_{X}
\end{aligned}
$$

where $g_{i}(i=R, X)$ denotes "guns" and $f$ and $c$, given the specialization of Robinson in the former and of Xena in the latter, are the total quantities of fish and coconuts produced. Note, then, that contrary to the neoclassical case

\footnotetext{
${ }^{6}$ Schelling (1960) was another exception that stimulated interest on the economic analysis of conflict and had much impact on the development of game theory more than twenty years after its publication. Its emphasis, however, was more on the "economics of conflict" rather than studying the effect of "conflict on the economy," which was Haavelmo's emphasis and the main topic of this article.
} 
of the previous section the number of fish and coconuts is variable. Given the assumption of linear homogeneity of the utility function that implies transferable utility, total utility $U(f, c)=U\left(e_{R}-g_{R}, e_{X}-g_{X}\right)$ is variable as well. $^{7}$ The more guns the two sides choose, the lower is the level of useful production and of total utility.

Guns are used to determine distribution. The two sides could fight it out and whoever turns out to be the winner would take possession and consume all of the fish and coconuts. Another possibility would be for the two sides to exchange some coconuts for some fish under the threat of fighting it out. In such a case guns would determine the bargaining power of each side. Let $p\left(g_{R}, g_{X}\right)$ denote Robinson's probability of winning in the event of a fight, with $1-p\left(g_{R}, g_{X}\right)=p\left(g_{X}, g_{R}\right)$ being Xena's probability of winning; that is, the probability of winning is symmetric. Naturally, it is assumed that the probability of winning of each side is increasing in its own quantity of guns and decreasing in the opponent's quantity of guns. ${ }^{8}$ Again, because of the linear homogeneity of the utility function it can be shown that the two sides would be indifferent between fighting and Robinson receiving a $p\left(g_{R}, g_{X}\right)$ share of fish, coconuts, and total utility with Xena receiving the remainder. Risk aversion, diminishing returns, destruction due to fighting, or additional resources needed to be devoted to fighting all would imply a greater set of peaceful alternatives, but the findings that follow do not qualitatively depend on exactly how the surplus over fighting is determined. Then, whether the two sides fight or settle peacefully under the threat of conflict, taking account the constraints in (1), the payoff functions are as follows:

$$
\begin{gathered}
V^{R}\left(g_{R}, g_{X}\right)=p\left(g_{R}, g_{X}\right) U\left(e_{R}-g_{R}, e_{X}-g_{X}\right) \\
V^{X}\left(g_{R}, g_{X}\right)=\left(1-p\left(g_{R}, g_{X}\right)\right) U\left(e_{R}-g_{R}, e_{X}-g_{X}\right)
\end{gathered}
$$

\footnotetext{
${ }^{7}$ The model examined here is similar to those in Hirshleifer (1988), Skaperdas (1992), Skaperdas and Syropoulos (1997), and Neary (1997). Esteban and Ray (1999) are examining some effects of unequal distribution and polarization. For some other recent work on the economics of conflict, see the introduction by Sandler (2000).

${ }^{8}$ Two functional forms of $p\left(g_{R}, g_{X}\right)$ that are employed in the literature are $\frac{g_{R}^{m}}{g_{R}^{m}+g_{X}^{m}}(m>$ $0)$ and $\frac{e^{k g_{R}}}{e^{k g_{R}+e^{k g} X}}(k>0)$. The former functional form has been extensively employed in the rent-seeking literature, with Tullock (1980) being the first to use it (with $m=1$ ). Hirhsleifer (1989) has explored the properties of both functional forms, whereas Skaperdas (1996) has axiomatized them as well as a wider class of functions.
} 
An increase in one side's guns increases the share of total utility received but decreases the production of consumables, fish in the case of Robinson and coconuts in Xena's case. This tradeoff appears when we take the partial derivative of each side's payoff with respect to own guns:

$$
\begin{aligned}
& \frac{\partial V^{R}\left(g_{R}, g_{X}\right)}{\partial g_{R}}=\frac{\partial p\left(g_{R}, g_{X}\right)}{\partial g_{R}} U\left(e_{R}-g_{R}, e_{X}-g_{X}\right)-p\left(g_{R}, g_{X}\right) \frac{\partial U\left(e_{R}-g_{R}, e_{X}-g_{X}\right)}{\partial f} \\
& \frac{\partial V^{X}\left(g_{R}, g_{X}\right)}{\partial g_{X}}=-\frac{\partial p\left(g_{R}, g_{X}\right)}{\partial g_{X}} U\left(e_{R}-g_{R}, e_{X}-g_{X}\right)-\left(1-p\left(g_{R}, g_{X}\right)\right) \frac{\partial U\left(e_{R}-g_{R}, e_{X}-g_{X}\right)}{\partial c}
\end{aligned}
$$

The first term in each of the two derivatives represents the marginal benefit of a small extra unit of guns whereas the second term represents the marginal cost of guns. Note how the second component of the marginal cost of guns is the marginal utility of the good produced by that side. Thus the higher the marginal contribution of one side, the higher is its marginal cost of guns. As we shall see shortly this property has significant implications for the pattern of distribution. A unique Nash equilibrium $\left(g_{R}^{*}, g_{X}^{*}\right)$ can be shown to exist under mild conditions. ${ }^{9}$ An interior equilibrium is characterized by setting (4) and (5) equal to 0 . By doing that it can be shown that

$$
\frac{\frac{\partial p\left(g_{R}^{*}, g_{X}^{*}\right)}{\partial g_{R}}}{-\frac{\partial p\left(g_{R}^{*}, g_{X}^{*}\right)}{\partial g_{X}}} \frac{1-p\left(g_{R}^{*}, g_{X}^{*}\right)}{p\left(g_{R}^{*}, g_{X}^{*}\right)}=\frac{\frac{\partial U\left(e_{R}-g_{R}^{*}, e_{X}-g_{X}^{*}\right)}{\partial f}}{\frac{\partial U\left(e_{R}-g_{R}^{*}, e_{X}-g_{X}^{*}\right)}{\partial c}}
$$

Under the same conditions that ensure existence of equilibrium, the lefthand-side of this equation can be shown to be greater than 1 if and only if $p\left(g_{R}^{*}, g_{X}^{*}\right)<1 / 2$ or if and only if $g_{R}^{*}<g_{X}^{*}$. Then, say, for Xena to be more powerful and receive the larger share of the total pie $\left(g_{R}^{*}<g_{X}^{*}\right)$, by

\footnotetext{
${ }^{9}$ For existence, it is sufficient that the contest success function $p(\cdot, \cdot)$ is not too convex in its first argument $\left(\frac{\frac{\partial^{2} p\left(g_{R}, g_{X}\right)}{\partial g_{x}^{2}}}{\frac{\partial p\left(g_{R}, g_{X}\right)}{\partial g_{x}}}<\frac{\frac{\partial p\left(g_{R}, g_{X}\right)}{\partial g_{X}}}{p\left(g_{R}, g_{X}\right)}\right)$. For uniqueness, it is sufficient that $p\left(g_{R}, g_{X}\right)=\frac{f\left(g_{R}\right)}{f\left(g_{R}\right)+f\left(g_{X}\right)}$ for some positive and increasing function $f(\cdot \dot{)}$. Proofs can be found in Skaperdas and Syropoulos (1997).
} 
(6) we must have $\frac{\partial U\left(e_{R}-g_{R}^{*}, e_{X}-g_{X}^{*}\right)}{\partial f}>\frac{\partial U\left(e_{R}-g_{R}^{*}, e_{X}-g_{X}^{*}\right)}{\partial c}$, or that Xena must be less marginally productive at the equilibrium point. To facilitate comparison with the simple exchange model of the previous section, let $e_{R}=e_{X}=E$. It can then also be shown that Xena is more powerful if and if only if $\frac{\partial U(E, E)}{\partial f}>$ $\frac{\partial U(E, E)}{\partial c} .{ }^{10}$ Note that this is the exact opposite outcome from the case of completely secure property rights that we discussed earlier. When property is insecure, the side that is more productive has a comparative disadvantage in grabbing and, in equilibrium, it prefers to contribute relatively more to production and relatively less to guns which in turn results in lower welfare than its opponent. The less productive side has a comparative advantage in grabbing as it faces a lower opportunity cost of guns (in terms of useful production) and receives a bigger part of the total pie.

We do not have to go far back in history to find evidence of the relationship between productivity and power. It appears that warriors, knights, lords and generally specialists in violence appeared to have enjoyed higher consumption than the peasants who were the actual producers and over which those specialists ruled. Further, many long-distance merchants and traders like the colonizing Phoenicians and Ancient Greeks, Genovese, Venetians, Vikings or the first Arabs who spearheaded the spread of Islam, were all primarily superior warriors and only secondarily could they be considered traders.

Of course, the possibly inverse relationship between productivity and power is just a tendency that is not absolute. Someone who is better compensated could have the absolute advantage in production as well. But allowing for appropriation casts serious doubt on the presumption that those who are better compensated are also necessarily more productive, a presumption that appears widespread in empirical assessments of relative worth. Moreover, regardless of absolute advantage, the dynamic incentives created by the possible static disadvantage that higher productivity confers can be seemingly perverse. As Gonzalez (2001) shows, even superior technologies that available at zero cost could be easily rejected in favor of inferior technologies that would not provide the strategic disadvantage of the superior technologies. The water mill for example had been used by the first century AD in the Roman world but was not generally adopted until the eleventh century. Similar fates had befallen numerous other innovations from the classical world as well as

\footnotetext{
${ }^{10}$ For the proof, see Skaperdas (1992). For additional comparative static results of a more general model, see Skaperdas and Syropoulos (1997).
} 
China (see Baumol, 1990, for examples and arguments).

Another obvious difference from the received economic model of exchange concerns the costs of arming and conflict themselves. ${ }^{11}$ These costs can be both static and dynamic. In growth models that allow for appropriation, either as non-durable output (Grossman and Kim, 1996, Mehlum et. al., 2000) or as durable non-productive 'enforcive' capital (Lee and Skaperdas, 1998), its growth-stunting effects become compounded over time. If we were to briefly reflect on the types of capital and large-scale organizations that most human societies had created up to about two centuries ago, we can easily see that it had been heavily weighed towards the appropriative type; protective walls, castles and moats, elaborate siege machines. No civilian equivalent could approach the organizational and logistical sophistication of many armies.

More concretely, Hess and Pelz (2002) have recently attempted to put a lower bound on the direct welfare costs of conflict. For countries like Guatemala and Ethiopia they estimate these costs to range from 13 to 44 percent of their consumption (Hess and Pelz, 2002, Table 4). These costs dwarf the potential gains from eliminating business cycles, as calculated in Lucas (1987). Other recent work shows how conflict impinges on economic growth (Rodrik, 1998) and the quantitative effects and sources of civil wars (Collier and Hoe- er, 2000, Reynal-Querol, 2002, and the survey by Sambanis, 2001). And from a longer term perspective, the twentieth century, the century with the most accelerated change, has also seen the highest estimated per capita numbers of deaths than any other century for which we have reasonable estimates (Mazower, 1998). Based on such evidence we would normally expect as much attention being given to the issue of domestic and international conflict, especially in developing countries, as it is given to the problem of business cycles in macroeconomics. Moreover, the estimates by Hess and Pelz are truly lower bounds. They do not include the cost of defense and other security expenditures that can vary enormously across countries with otherwise the same characteristics except for the level of internal or external

\footnotetext{
${ }^{11}$ I have not distinguished here the conditions under which actual conflict occurs versus those that settlement under the threat of conflict takes place. Incomplete information is obviously one possible reason for parties engaging in actual conflict despite its additional costs (for formal models on this point, see Brito and Intriligator, 1985, and Bester and Warneryd, 2000). Actual conflict can also occur without incomplete information because of the compounding rewards to the winner of a conflict, a point that we will discuss in the next section.
} 
security they face. And they do not also include the aforementioned long-run dynamic effects of capital accumulation and technology adoption.

Up to this point we have maintained that appropriative expenditures and other associated costs are literally due to arming. There are however numerous other forms of appropriative activities that are important and are very different from arming. Whether private or public, almost all organizations are not organized as markets but as bureaucracies. At least some activities within bureaucracies can be considered to be influence activities which have been modelled in a broadly similar fashion to the model described above (see, e.g., Milgrom, 1988, or Mueller and Warneryd, 2001). The problem of the conflict between shareholders and managers is of course very old and at least one part of Russia's dismal economic performance during the 1990s, where asset-stripping and outright stealing of productive assets in the face of weak legislation and enforcement have been rampant. ${ }^{12}$ Other activities that can be, at least partly, considered appropriative include litigation expenditures (Farmer and Pecorino, 1999, Hirshleifer and Osborne, 2001) and of course lobbying, 'corruption,' and rent seeking.

How much of such activities can be considered unproductive or nonproductive and therefore in some need of control and governance is not a priori clear. However, the point is not where precisely to draw the line but the need to look more closely to the vast world of non-market activities; to begin recognizing that the governance of those activities takes a significant portion of human resources; and that we cannot keep assuming that all these activities are simply deviations or distortions of an ideal world of costless market interactions in which everybody behaves as a saint, except when they need to haggle over price.

We next turn to a necessarily brief overview of some ways that economists have considered as restraining the dark side of self interest.

\footnotetext{
${ }^{12}$ For a survey of the many problems that can emerge in corporate governance, see Shleifer and Vishny (1998). For examples from Russia, see Blasi et. al. (1997) or Klebnikov (2000).
} 


\section{On the Traditional Response: The Folk The- orem and the Social Contract}

Prominent economists and classical liberal philosophers from Adam Smith to Hayek and Buchanan have always been aware of the importance of both moral constraints and respect for the law on the part individuals in a modern economy and society. However, to my perhaps limited knowledge, that attitude is considered necessary on normative grounds, not derived as part of the equilibrium behavior of self-interested agents. (See, for example, Part II of Hayek, 1960, or Buchanan, 1977.) Filling this apparent hole, then, has been the subject of a wide-ranging effort on the part of economists, game theorists, and rational-choice political scientists over the part twenty five years or so.

The main argument is based on the repeated interaction of individual agents using the "folk theorem" (see, for example, Fudenberg and Tirole, 1991, Chapter 5, for the generic game-theoretic approach and to Greif, Bates, and Singh, 2000, and Muthoo, 2000, for applications to problems similar to the ones examined here). When the future is highly valued, parties can condition future cooperation on present cooperation and therefore cooperative equilibria can exist in which no guns, or at least fewer guns, are produced and all parties are better off than they would be under one-time interactions. Thus, when the "shadow of the future" (Axelrod, 1984) is long enough, Xena and Robinson could be better off that they are under the $\left(g_{R}^{*}, g_{X}^{*}\right)$ equilibrium we discussed earlier.

Repeated interactions and the shadow of the future can increase, and have undoubtedly increased in certain instances in the past, the chances of cooperation from the case of tribal societies to those of feuding modern elites. Their importance, however, for the emergence and evolution of governance has been overemphasized. Arguments based on the folk theorem can only be used to establish the possibility of cooperation. The conflictual equilibrium is always an equilibrium and in many respects it is the most robust one: the strategies that implement it are computationally less complex, they are renegotiation-proof, and it can be argued that they are more focal than the typical multitude of supergame strategies. Even if a cooperative equilibrium were to emerge, as argued in more detail in the next section, in many instances the "contract" that can be expected to emerge would not be Rousseau's horizontal one but more like a Hobbesian vertical contract. ${ }^{13}$

\footnotetext{
${ }^{13}$ The characterization of contracts employed here has been used by Hirshleifer (1995,
} 
Furthermore, a longer shadow of the future, instead of increasing the chance of cooperation, could actually aggravate conflict and even induce it. Think of Xena and Robinson, isolated in an island with fixed resources, and having to interact over time. Perhaps they would indeed decide and disarm, but what about the possibility of fighting it out to the end, so that only one is left on the island who will thereafter enjoy all its fruits without having to share them with the other? That is, despite the costliness of arming and conflict, when rewards to winning spill into the future, the adversaries could fight much harder, and the longer the shadow of the future is the more intense arming and fighting can become. ${ }^{14}$ Much ethnic conflict, for example, could be attributed to the apparent intense desire key participants have for a certain piece of land belonging to the future generations of their kind, to the extent that they are willing to sacrifice their own lives. Likewise, arguments of the "falling-domino" variety, regardless of whether they are right, are based precisely on acute concern and high valuation of future outcomes.

To illustrate how conflict can be induced by a longer shadow of the future consider an example in which we distinguish between conflict and settlement under the threat of conflict. Suppose that Robinson and Xena care not just about what occurs today but also about what will occur tomorrow; that is, we can think of the game as having two periods. For simplicity assume in each period there is an economic surplus of $T$ units to be allocated between the two adversaries and that guns in each period are fixed at levels $\hat{G}_{R}$ and $\hat{G}_{X}$ for Robinson and Xena. If the two parties were to fight it out some of the surplus $T$ would be destroyed and only $\alpha T(\alpha \in(0,1))$ would be left for the winner. Therefore, looking at every period in isolation, the two parties would always be better off dividing the surplus in accordance with their winning probabilities than fighting it out. Given guns and the associated probabilities of winning, $\hat{p}$ and $1-\hat{p}$, Robinson and Xena can either fight or settle. In a particular period if they were to settle, Robinson would receive $\hat{p} T$ and Xena $(1-\hat{p}) T$. If they were to fight, Robinson would have an expected payoff of $\hat{p} \alpha T$ and Xena would have an expected payoff of $(1-\hat{p}) \alpha T$. This preference for settlement, however, does not necessarily hold when the two sides take

2001)

${ }^{14}$ Skaperdas and Syropoulos (1996) show how such time-dependence increases arming as the discount factor increases. Garfinkel and Skaperdas (2000) distinguish between actual conflict and settlement under the threat of conflict, and show how actual conflict becomes more likely as the discount factor increases. The example below is based on the argument of the second paper. 
account the effect of the future.

Consider now the decision between fighting and settling today, after the two sides have armed, and taking account the effect of tomorrow. For simplicity suppose that if they were to fight today, the loser would be eliminated and the winner could enjoy all the surplus by himself or herself tomorrow and do that without having to incur the cost of arming. Letting $\delta \in(0,1)$ denote the discount factor for tomorrow, Robinson's payoff from settlement - which would also imply settlement tomorrow as well - would be $\hat{p} T+\delta\left(\hat{p} T-\hat{G}_{R}\right)$. Similarly, the settlement payoff for Xena would be $\left((1-\hat{p}) T+\delta\left((1-\hat{p}) T-\hat{G}_{X}\right)\right.$. The expected payoffs from fighting, again as of today, would be $\hat{p} \alpha T+\delta \hat{p} T$ and $(1-\hat{p}) \alpha T+\delta(1-\hat{p}) T$. It is simple to show that the two sides will settle if and only if $\delta \leq \min \left\{\frac{\hat{p}(1-\alpha) T}{\hat{G}_{R}}, \frac{(1-\hat{p})(1-\alpha) T}{\hat{G}_{X}}\right\} .{ }^{15}$ That is, the two sides compromise when they do not value the future highly enough and fight when they value the future more highly, the exact opposite of what occurs under folk theorem arguments. Higher discount factors would also induce higher equilibrium levels of guns, if guns were allowed to be endogenously determined. The key to such outcomes is the inability of the contending parties to make long-term commitments on guns.

Overall, the argument that repeated interactions and high values placed in the future will by themselves solve the fundamental problem of restraining the dark side of self interest is unsustainable both theoretically and empirically. Otherwise, they would be no need for laws, courts, constitutions, treaties, contracts, enforcement agencies, and all the institutions and organizations of governance, for individual agents could do without them if they just had long enough time horizons.

\section{Hierarchies, Kings, and Lords}

For the overwhelming part of human history and still for much of the world today, autocracy has been the main form of governance. It would be hard to imagine how this outcome could emerge out of the repeated prisoners'dilemma stories that are often been told as parables for the emergence of state organization. However, the emergence of hierarchy and autocracy can

\footnotetext{
${ }^{15}$ If $p=G_{R} /\left(G_{R}+G_{X}\right)$, then the equilibrium choices of guns for both sides can be shown to equal $\alpha T / 4$ and the critical discount factor would equal $2(1-\alpha) / \alpha$. Thus the less destructive conflict is, the higher is the critical discount factor below which settlement ensues.
} 
make sense within the simple model of Robinson and Xena we have examined. One element we can use is the basic asymmetry in productive capacities, and thus in power, that exists between the two adversaries. If anything, in considering dynamic versions of such interactions, any initial asymmetries are likely to be compounded over time with the more powerful adversary becoming stronger. ${ }^{16}$ The two sides, then, could save some resources by agreeing on an asymmetric, hierarchical contract in which the more powerful agent is recognized as such, as lord, and has a larger claim on the surplus; the lord and his subject can then expend only a fraction of the resources in guns that are expended under one-time interaction.

To make a more nuanced evaluation of autocracies however we need to consider more dedicated models, which we will discuss shortly. The provision of security - from providing protection against common crime to managing conflict among organized interests - can be considered the defining characteristic of the state, for the other functions that states may undertake cannot be fulfilled without security. The problem with states, especially autocratic ones, however, is that they can hardly be considered disinterested in providing security. If those who control the means of violence can pacify their territories, what prevents them from taking away whatever they can from their subjects? Or, to put it differently in the more familiar question, who is going to guard the guardians? This is the fundamental problem of governance which in its various manifestations - not just in government but in private bureaucracies as well - arguably poses the biggest challenge to economic performance.

\subsection{Monopolistic Autocracy ${ }^{17}$}

Olson (1991) and somewhat more emphatically McGuire and Olson (1996) have argued that a "stationary bandit," a king or lord who has a reasonable expectation of maintaining his position for some time, can actually have the

\footnotetext{
${ }^{16} \mathrm{~A}$ more detailed description and discussion of such a model can be found in Skaperdas and Syropoulos, 1995, pp. 70-74). For a connection to the work on hierarchy and authority in the other social sciences, see Zambrano (1999).

${ }^{17}$ An alternative name for the type of state I discuss here is the "proprietary" state, the state that is run for the benefit of their rulers and their circles. To my knowledge, the term has been used first by Grossman and Noh (1994). It should be dinstiguished from the term "predatory" (see, eg, Robinson, 1997), in the sense that all proprietary states need not be predatory.
} 
incentives to provide a measure of good governance. ${ }^{18}$ The stationary bandit, as the proprietor of the state, provides protection against bandits and robbers using a more efficient technology of protection that can be provided privately by each individual producer. ${ }^{19}$ Because collective protection can be provided more efficiently and fewer resources are needed to provide the same level of protection as under a hypothetical anarchy, output should in principle be higher under autocracy than under anarchy. That also implies that more security can be bought with a smaller fraction of the population resorting to banditry and robbery. Higher security can in turn induce the ruler to provide the more traditional infrastructural public goods and stimulate trade and economic development. With a longer time horizon, the profit-maximizing proprietor could lower tribute so that he can stimulate these economic forces even further.

What is a necessary condition, however, for a profit-maximizing ruler to follow non-extortionary taxation and growth-promoting expenditures on public goods is a high degree of certainty that he will be around in the future to reap the rewards of such policies. Since the internal and external challengers to the power and profits of autocrats typically abound, their position can be precarious. Those who have been in power the longest could even be the most paranoid about the future - as Wintrobe (1998, p.39) argues, paranoia is the characteristic personality trait of dictators. The optimal policy of the ruler could then well be the extraction of maximal revenue for the short term. Because the ruler can have greater extractive powers than simple bandits have or because not enough protection is provided by the ruler, producers could be even worse off than under anarchy. (See Moselle and Polak, 2001, and Konrad and Skaperdas, 1999, for formal models that allow

\footnotetext{
${ }^{18} \mathrm{~A}$ number of articles by economists have examined the problem during the past decade or so. To my knowledge, Findlay (1990) was the first to specify a model of the autocratic state within an optimizing framework. Besides McGuire and Olson (1996), others include Grossman and Noh (1994), Hirshleifer (1995), Marcouiller and Young (1995), Skaperdas and Syropoulos (1995), Robinson (1997), Konrad (1999), Konrad and Skaperdas (1999), and Moselle and Polak (2001). Wintrobe (1998) has engaged in an in-depth examination of dictatorships, as he considers the many different control problems that dictatoships typically face. Usher (1989) has developed an elaborate model of anarchy out of which autocracies may emerge.

${ }^{19}$ McGuire and Olson (1996), as well as Findlay (1990) and others, model the services provided by the state as an ordinary public good, without any explicit reference to the provision of security. The interpretation discussed here follows that of Konrad and Skaperdas (1999).
} 
for such possibilities, and Marcouiller and Young, 1995, for a model similar to McGuire and Olson's but which can also lead to a disastrous "black-holeof-graft" outcome.)

The presence of a long horizon that comes from a low uncertainty of future rule by a ruler with an "encompassing interest," though, is by no means sufficient for following growth-promoting policies. For, as Robinson (1997) has argued, many such policies can be at the expense of autocratic rule in the long run. Promoting trade implies that merchants becomes richer and perhaps ask for more rights and a share of power; expanding education can make more of the population become conscious of its subservient status and demand reforms and a change in the status quo; even building roads can make it easier for rebels to reach the capital and drive out the ruler. ${ }^{20}$ Thus, long-term survival may well be incompatible with providing the infrastructure public goods that are necessary for development. Robinson's (1997, pp. 23-26) review of the evidence on dictatorships suggests that those with dynastic pretensions and therefore longer horizons have been the most predatory during the twentieth century. Similarly, the dynastic empires of Spain, Russia, or Ancien Regime France were very slow to adopt growth-promoting policies compared to the other more liberal regimes in Europe and, from the eighteenth century onward, compared to the emerging national states.

Overall, then, there is no theoretically or empirically convincing case to be made that a for-profit, proprietary state will necessarily bring an improvement in the material welfare of its subjects. After all, up to less than two centuries ago there were virtually no other types of states and their contribution to material growth had been at best questionable. However, one factor that has been argued to have taken some of the rough edges off autocracies in the West and have very gradually (and, grudgingly, on the part of rulers) led to the developmental policies is competition among such states (e.g., North and Thomas, 1973).

\footnotetext{
${ }^{20}$ I cannot resist reproducing the following statement (quoted in Robinson, 1997, p.2) by former President of Zaire Mobuto Sese Seko to President Juvenal Habyarintha of Rwanda: "I told you not to build any roads... Bulding roads never did any good.. I've been in power in Zaire for thirty years and I never built one road. Now they are driving down them to get you." Of course, President Mobuto was following the same policies of the former masters of Congo, the Kings of Belgium and especially King Leopold.
} 


\subsection{Competing Autocracies}

Extrapolating from competition in ordinary economic markets we could expect that competition in the provision of protection and security would also be beneficial. The typical argument runs as follows: Rulers who maximize the difference between tax revenue and the cost of services provided will offer lower taxes and a higher service level, the more rulers there are around. This is because the customers/subjects will tend to be attracted to the rulers with the best combination of tax rates and services. For this type of competition to work, there are two necessary conditions. First, the movement of subjects across states should be of low enough cost. Second, each ruler can commit to their announced tax rates and service provisions - for, otherwise, subjects who are lured in a state face the threat of expropriation once they have chosen their location and have become producers there. If rulers cannot commit, then taxation is determined by the relative power of the two sides: the brute strength of the ruler versus the tax-resistance capabilities of the subjects. Failure of either condition - mobility of subjects or the ruler's ability to commit - cannot guarantee that tax competition among autocratic states will bring about the beneficial outcomes of competition expected in ordinary economic markets.

However, in much of history competition among proprietary rulers appears to have been much less like competition among mineral water producers and more akin to competition among mafia lords. Mafiosi compete less on the prices they charge for protection and more through fighting for, and protecting, their turf. Likewise, rulers have typically worried much more about the armies of their competitors across their borders than about how the fiscal policies of their competitors affect the movement of their subjects. Indeed, autocratic states had to devote most of their resources to defending their territories, with the tributary subjects within them, and fighting against other states. Because those resources expended on arming and fighting are kept away from production and consumption, such competition has very different effects from those of price competition. For other things equal, greater competition - in the sense of having a greater number of states implies that a greater amount of resources is expended on conflict, which can in turn create greater uncertainty for the fate of the rulers themselves and for the production and investment decisions of the subject populations. Such warlord competition can be worse than atomized anarchy and can be characterized as a higher level of organized anarchy. (For a model of this type 
of competition and its effects, see Konrad and Skaperdas, 1999. In Azam (2002), though warlords are taken to maximize the welfare of their group and not strictly their own take, the effects can be still be pretty dismal.)

Which type of competition has been most important? The former type of economic competition among autocratic rulers is virtually the sole form of competition really considered but has most likely been overrated. If it were the main form of competition among rulers, even in the West, the world would have developed materially a long time ago. Autocratic rulers can behave differently, though, when they do not face just other autocratic rulers but are under the pressure of economic competition from less autocratic regimes. They can then be forced to provide tax and other privileges. This is the force - the pressure from city states in Italy and the Nertherlands, and from England whose rulers had more restrictions in their power - that Tilly (1992) has identified as those that operated in the West and which gradually induced more economic forms of competition. Autocratic rulers, left by themselves, find more profitable to just fight one another for territory and the tributary subjects that come with it.

Even today, this fighting-for-rents competition is not confined to mafias and gangs. Former President Mobutu Sese Seko certainly was not afraid that his subjects would flee to the greener pastures of other states, although some of them undoubtedly did, and policies of his successors do not appear any different. If anything, from Colombia to many other areas of Africa, to Afghanistan, and many post-Soviet republics, that competition for rents by rulers threatens to become even more important in the medium run.

Overall, though autocratic rule can increase security and help provide other public goods, it often recreates the problems of conflict in anarchy at a higher and more organized level. Autocrats can extract more efficiently from producers than simple bandits can and fighting among such rulers moves the problem of restraining self-interest from individuals to organizations and groups. The political experimentation of the past two centuries, though rather new to assess especially in terms of long-term viability, appears to have been effective in providing at least some answers to the fundamental problem of governance. 


\section{Restraints in Modern Governance}

Over the past two centuries the tremendous expansion of markets has been primarily of the variety that Olson (2000, Chapter 10) has labelled socially contrived markets (as opposed to self-enforcing ones). In these markets, individual participants face potential enforcement problems and other prerequisites that are much more complex than those faced by our example of Robinson and Xena. Take for instance the market for real-estate mortgages. To begin with, the owner of the land and other structures needs to have clear title, something that requires well-defined laws, courts that will enforce them, land registries and other government agencies that oversee zoning and related land regulations, reliable insurance that will cover many contingencies, and every step along the way has to be free of corruption. These attributes might appear to Western eyes easy to satisfy, but they are expensive to set up and difficult to institute in practice. For example, in Russia only recently legislation was voted on the private ownership of land in cities and still no such laws exist for land in rural areas. Clear title is just a prerequisite. The obligations of the lender and borrower, bankruptcy laws and their enforcement, various asymmetries of information are typically even more complex than clarity of title. To have the secondary mortgage market that exists in the United States, another set of complex conditions needs to be satisfied.

Underpinning all the above is a very high degree of confidence on the part of all market participants that none of the contractual terms, the basic laws, and their enforcement will change during the life of the loan. That is, market participants need to have high confidence that whoever is in power cannot change much that concerns them. It is difficult to see how an autocrat with few restraints could inspire enough confidence so that markets such as today's mortgage markets could evolve.

In the West, modern governance evolved out of Absolutism, with a patchwork of restraints, piecemeal extensions of the franchise and other rights, and civil service reorganizations gradually and haltingly introduced. Its main characteristics include checks and balances, separation of powers, formal representation, bureaucratic form of organization, as well as the loyalty of the citizens of national states. I will next argue that these characteristics can, at least partly, be seen as ways of restraining the dark side of self-interest of individuals, organizations, and rulers. My presentation will necessarily be selective, tentative, and speculative at times since economists have done so little work in the area. It therefore also represents somewhat of an agenda 
for future research.

\subsection{Representation, Checks and Balances}

Representative government and checks and balances have often began with restraints on the power of rulers that have come about after protracted civil wars. According to North and Weingast (1989) it took almost the whole seventeenth century in England for the Parliament (consisting of nobles) to develop just the beginnings of an effective and lasting check on the powers of the Crown. This check on the power of the Crown and transfer of conflicts from the battlefield to the political and judicial arenas were according to North and Weingast critical for the subsequent developments in England and in the wider area of Northwestern Europe. However, the process of conflict and settlement that took place in seventeenth century England was by no means unique in Europe (or beyond it), and it took various other forms. Earlier, for example, in twelfth century Genoa, after decades of unresolved civil wars the feuding clans agreed on the institution of the podesta, an outsider noble who served for a limited term of one year as administrator and judge but who had enforcement powers limited enough to safeguard against takeover in alliance with one of the clans (See Greif, 1998). Other Italian cities in late Medieval times developed locally adapted institutions of conflict management that were part of the institutional stock of knowledge that could be used in the subsequent centuries.

The English Crown did not cede some of its power out of the goodness of their Kings' hearts. Many of the developments in modern governance over the past two centuries that have benefited wider segments of the population - the extension of the democratic franchise, land reforms, labor legislation, welfare programs - could be interpreted to have emerged under pressure as conflict-alleviating devices. Land reform can be a rational response of landowners who can be better off by giving up some of their land which in turn induces considerably less conflict and banditry (Horowitz, 1993, Grossman, 1994). Employment subsidies can similarly be instruments of conflict resolution (Zak, 1995, Grossman, 1995). Generically, Rajan and Zingales (2000) have shown that in variations of the basic model of section 3 one side can bring about a Pareto improvement by voluntarily transferring ex ante (that is, before the choices of guns are made) some of its initial resources to the other side. However, the range of parameter values over which such ex ante transfers are Pareto-improving can be narrow or non-existent, and even 
if they are not the savings from reduced conflict are small compared to the gains that can be brought about by more drastic conflict-reducing measures.

Such a drastic measure is implementing transition to a new regime with rulers that are very different. Rosendorff (2001) argues that the transition from apartheid in South Africa was engineered by a cost-benefit calculation on the part of the white ruling elite there. Rosendorff models apartheid as a conflictual regime with the type of inefficiencies we have examined in this paper, whereas under democracy, as the median voter is poor (and mostly black), there is redistribution from the rich (and mostly white) to the poor. Under circumstances that Rosendorff argues were about those prevailing in South Africa around transition time, the losses that the rich whites would incur under democracy were deemed to be lower than those due to conflict, thereby precipitating transition from apartheid.

Acemoglu and Robinson (2000) make a similar argument about the extension of the democratic franchise in Britain during the nineteenth century, albeit using a dynamic model that takes account of an additional possibility: the fact that the ruling elites could have possibly replicated the economic outcome of democracy through systematic transfers and without extending democracy. However, as Acemoglu and Robinson argue, such transfers are not as credible as those that would come about if the poor were to hold a share of power. That is, extending the democratic franchise represents a level of commitment which, in a changing environment, cannot be credibly replicated by a stream of transfers that are not accompanied by a fundamental change in the rules of the game.

The relative social peace that has followed the extension of the democratic franchise and the variations of the welfare state that are to be found in the developed world appear to have contributed to the political stability that is a prerequisite for modern markets and which, in turn, further fuelled the material growth of the second part of the twentieth century.

\subsection{Bureaucracy}

New democracies, however, have their own problems of conflict. When a party attains power it often views government as its fiefdom, ready to be exploited just as it was by its former autocratic proprietors. Government positions are staffed by loyal supporters regardless of their qualifications and the positions are used for private gain; government contracts and loans are doled out to individuals and firms within the party's fold; and the power of 
government is used to weaken political opponents. All this can be perfectly legal as the legal framework is undeveloped. In the meantime, rent-seeking and corruption take place at all levels and actual, bloody conflict can easily take place between government and opposition. The behavior and economic effects of such governments can be more rapacious and short-sighted than those of many dictators. And these are not problems confined to banana republics. The now developed national states of the West have also gone through similar phases during their histories (e.g., Johnson and Libecap, 1994, for the corrupt functioning of the United States civil service in the nineteenth century).

The way Western national states have attempted to tackle these problems and continue to do so can be characterized as attempts to limiting the discretion of government officials and agencies. At the higher echelons this is accomplished through systems of checks and balances between the legislative, executive, and judicial branches of government. At the lower levels, discretion is limited through the professionalization of the bureaucracy and the creation of laws, rules, and procedures that attempt to patch the inevitable holes that are created by the evolving economy and society. Bureaucracy becomes professionalized by providing civil servants with security of employment that does not depend on which party is in power, salaries that are adequate to deter corruption for most, and a professional ethic and culture that insulates civil servants for everyday political struggles. Milgrom (1988) and Milgrom and Roberts (1990) have modelled influence activities within organizations and shown how the limiting of discretion, equity in compensation, and other procedures that seem inefficient in a market environment can be efficiency enhancing within organizations. Similarly, using the approach of Warneryd (1998), it can be shown that having more than one level of hierarchy in influence activities and rent-seeking can increase efficiency. ${ }^{21}$

The ideal disinterested bureaucracy has seldom been attained, of course, and it has many problems of its own, especially when all laws and rules are being applied "by the book." However the relevant comparisons should not be with an unattainable ideal but with the more probable alternative - found

${ }^{21}$ Max Weber's (1978) classic essay on bureaucracy can still be read with profit, whereas Wilson (1989) offers an excellent survey of the functioning of bureaucracies. Arguments complementary to those being made here have also been advanced using a traditional principal-agent approach (see Tirole, 1994, and Dixit, 1996). Using such an approach, multi-tasking and measurement difficulties lead to the adoption of the low-powered incentives that are typically observed inside bureaucracies. 
in the West's past and in the present of much of the rest of the world - of arbitrary, amateur, and frequently corrupt political control of the levers of government.

By the end of the nineteenth century, the bureaucratic form of organization became the dominant form of organization for private firms as well. Bureaucratization came hand-in-hand with the rise of the corporation as chronicled in Chandler (1977). Though the recent incomplete-contracts approach to the theory of the firm has emphasized the role of relationship-specific investments (Grossman and Hart, 1986), the control of some appropriative activities through the market may well be more difficult than through hierarchies. For example, much of trade across countries, which involves a greater degree of contractual insecurity than trade within countries, is intrafirm trade. ${ }^{22}$

\subsection{Homogeneity and the National State}

Industrialization and the tremendous expansion of markets over the past two centuries have been accompanied by a new type of state, the national state. ${ }^{23}$ We have already discussed some of its central characteristics, but another important one has been the striving of these types of states to homogenize the culture and language, and to gain the loyalty of the peoples within them. Before the advent of national states in Europe, the main form of governance was the absolutist empire. Peoples within them were from different ethnicities, spoke different languages, and adhered to different cultural practices. Their primary loyalty was to their own community and the identification with, and loyalty to, the state was essentially non-existent. In the largely static, agrarian world of the times such diversity appeared to function satisfactorily.

Expanding markets, the factory system, increased worker mobility, and the rise of bureaucracy all implied that people from very different backgrounds had to come in contact with one another and cooperate in numbers that were historically unprecedented. To communicate with your co-workers in the factory floor and, even more importantly, for the expanding bureaucracy to function effectively, having a common language of communication

\footnotetext{
${ }^{22}$ In the late 90s over 50 percent of US and Japanese trade was intrafirm trade (Gilpin, 2001, p.210).

${ }^{23}$ Another name that has been used is the "nation-state." For the variety of types of states in history, see Finer (1997) or Mann (1986). For a perspective on the rise of the national state, see Tilly (1992); its main competitor was the absolutist empire.
} 
certainly would help. Beyond language, adherence to social and cultural norms that were not just those of the former peasants' village facilitated cooperation in the emerging greater society. Public education and the striving towards universal literacy contributed not just this industrial social organization, but also to the loyalty of citizens towards the state in ways that many of them were willing to sacrifice their lives in war. This is, very briefly, Gellner's (1983) "one state, one culture" theory of the national state. (For an economist's perspective of some other aspects of Gellner's approach, see Findlay, 1995.) Gellner's theory can be thought of as a hypothesis of the homogenization of $L$ (Labor) so that it can enter the production function $F(K, L)$. The linguistic and cultural homogeneity that developed in the most successful national states along with the loyalty of their citizens facilitated the cooperation in factory floors, markets, and politics, and thus reduced the older forms of appropriation within these states. Of course, the same very strong forces of cooperation within national states also made possible the horrendously destructive wars of the first part of the twentieth century. Still, though, the forces unleashed by national states have been considered to be beneficial on balance and the experience of the second part of the twentieth century indicates that some learning has taken place about controlling conflict at the transnational level. ${ }^{24}$

Overall, my purpose in this section has been to present some ideas that have already appeared within economics or other disciplines that hold promise for understanding how modern governance relates to the economy. This way the correlation of the tremendous growth of the state alongside capitalism and markets that has occurred over the past two centuries can begin making sense. Otherwise, if we were to follow received economic theory literally and consider government either as a disinterested provider of public goods or as an aberration, we will have trouble making sense of the past two centuries.

\footnotetext{
${ }^{24}$ Economists have recently considered the age-old problems of the effects of democracy and trade on conflict. For a beneficial effect of democracy on conflict see Garfinkel (1994) and for a more skeptical view see Hess and Orphanides (2001). For the effect of trade on conflict that incorporates both the classical liberal and realist perpsectives, see Findlay and Amin (2000) and Skaperdas and Syropoulos (2001).
} 


\section{Concluding Remarks}

Imagine the U.S. stock markets without a Securities and Exchange Commission or its equivalent, without the elaborate insider trading rules that have evolved to reduce cheating by managers, without accounting standards and other regulation. Could we rely on the goodwill of each firm's managers to produce accurate accounting of their profits, not selling to their friends and relatives at prices below market and using their office in the myriad other ways that are possible for private enrichment? Perhaps, in the absence of any government involvement and despite the many contrary experiences in the rest of the world, the interested parties could come together and self-regulate in an effective fashion. Whether that could occur or not, however, the issue is that cheating by managers is an important real world problem that is also a relevant scientific problem for the economist. I have argued that the costs associated with restraining self-interest and its control are large and they deserve much more attention than they have received within economics. Highly paid managers, accountants, lawyers, and less well-paid regulators and secretaries are all involved in the business of engaging in or controlling the dark side of self interest. So are policemen, gangbangers, mafiosi, judges, spies, diplomats, and army generals. The costs of these activities represent a large share of national incomes,${ }^{25}$ and the relevant inputs can hardly be modelled as entering ordinary production functions; as shown in this paper, when some of this activity is modelled as appropriation central results of received theory are overturned.

Yet both modeling and, most importantly, the explicit or implicit normative analyses of many economists and economic policymakers is based on an ideal world without costly appropriation or measures that attempt its control. Although they might recognize that such activities play a role in the economy, their analyses is based on the framework that has been elaborated since the time of Edgeworth and which does not explicitly allow for appropriation. Frameworks of analysis and ideas have an independent existence and can shape the world powerfully. To repeat the Keynes' often-quoted remarks:

... [T] he ideas of economists and political philosophers, both when

\footnotetext{
${ }^{25}$ For estimates of the transaction sector of the US economy, which includes many of the enforcement and other costs examined in this paper, see Wallis and North (1986). Marselian (1998) has examined the cross-country relationship of different parts of these costs and macroeconomic variables.
} 
they are right and when they are wrong, are more powerful than is commonly understood. Indeed the world is ruled by little else. Practical men, who believe themselves to be quite exempt from any intellectual influences, are usually the slaves of some defunct economist. Madmen in authority, who hear voices in the air, are distilling their frenzy from some academic scribbler of a few years back.

Keynes, 1964[1936], p. 383.

Nowadays, practical men, if not madmen in authority, in many governments and international organizations have a world-view that is encapsulated in the received first-best model of section 2 in which there is no dark side to self interest. The primary criterion of evaluation in that model and that worldview is a narrow notion of economic efficiency that abstracts away from the direct and indirect costs of conflict and appropriation. That cannot go, and has not gone, very far in understanding the sources of economic performance in the modern world. The recent research in economics that I have partially reviewed here is a promising start. Thus, if we were to agree with Keynes, who immediately after the passage quoted above wrote "I am sure the power of vested interests is vastly exaggerated compared with the gradual encroachment of ideas" (p.383), we could be optimistic. However, the fact that ideas of a truly integrated politico-economic model and a correspondingly wider notion of efficiency have not progressed that much over more than a century of economic thought might give us pause and think that the power of vested interests could be more important than Keynes believed them to be. 


\section{REFERENCES}

Acemoglu, Daron and Robinson, James, "Why Did the West Extend the Franchise? Democracy, Inequality and Growth in Historical Perspective," Quarterly Journal of Economics, November 2000, 115, 1167-1199.

Anderson, James E. and Marcouiller, Douglas, "Trade and Security I: Anarchy," October 1997, Department of Economics, Boston College.

Anderton, Charles, Anderton, Roxanne, and Carter, John R., "Economic Activity in the Shadow of Conflict," Economic Inquiry, 1999, 37, 166-179.

Axelrod, Robert, The Evolution of Cooperation, 1984, New York: Basic Books.

Azam, Jean-Paul, "Looting and Conflict Between Ethno-regional Groups: Lessons for State Formation in Africa," Journal of Conflict Resolution, February 2002, 46(1), 131-153.

Baumol, William J., "Entrpreneurship: Productive, Unproductive, and Destructive," Journal of Political Economy, 1990, 98, 893-921.

Bester, Helmut, and Warneryd, Karl, "Conflict Resolution Under Asymmetric Information," September 1998.

Blasi, Joseph R., Kroumova, Maya, and Kruse, Douglas, Kremlin Capitalism: Privatizing the Russian Economy, 1997, Ithaca, NY: Cornell University Press.

Bowles, Samuel and Gintis, Herbert, "The Revenge of Homo Economicus: Contested Exchange and the Revival of Political Economy," Journal of Economic Perspectives, Winter 1993, 7(1), 83-102.

Brito, Dagobert and Intriligator, Michael, "Conflict, War and Redistribution," American Political Science Review, 1985.

Buchanan, James, The Limits of Liberty: Between Anarchy and Leviathan, 1975, Chicago: University of Chicago Press.

Chandler, Alfred D., The Visible Hand: The Managerial Revolution in American Business, 1977, Cambridge, MA: Belknap.

Collier, Paul and Hoe- er, Anke "Greed and Grievance in Civil War," January 2001, World Bank.

Dixit, Avinash, The Making of Economic Policy: A Transaction-Cost Politics Perspective, 1996, Cambridge, MA: The MIT Press.

Edgeworth, Francis Ysidro, Mathematical Psychics, 1881, London: C. Keegan Paul \& Co.

Esteban, Joan M. and Ray, Debraj, "Conflict and Distribution," Journal of Economic Theory, 87, 379-415. 
Farmer, A. and O. Pecorino (1999) "Legal Expenditure as a Rent Seeking Game", Public Choice, September, 100: 271 - 288.

Findlay, Ronald, "The New Political Economy: Its Explanatory Power for the LDCs," Economics and Politics, 1990, 2, 193-221.

Findlay, Ronald, "Notes on the Political Economy of Nationalism," in Breton, A., Galeotti, G., Salmon, P., and Wintrobe, R. (eds.), Nationalism and Rationality, 1995, pp. 143-158, New York: Cambridge University Press.

Findlay, Ronald, "Towards a Model of Territorial Expansion and the Limits of Empire," in G.R. Garfinkel and S. Skaperdas (eds.), The Political Economy of Conflict and Appropriation, 1996, New York: Cambridge Unviersity Press.

Findlay, Ronald and Amin, Mohamed, "National Security and International Trade: A Simple General Equilibrium Model," November 2000, Columbia University, Department of Economics.

Finer, Samuel, E., The History of Government I: Ancient Monarchies and Empires, 1997, Oxford: Oxford University Press.

Fudenberg, Drew and Tirole, Jean, Game Theory, 1991, Cambridge, MA: MIT Press.

Garfinkel, Michelle R., "Domestic Politics and International Conflict," American Economic Review, December 1994, 84(5), 1292-1309.

Garfinkel, Michelle R. and Skaperdas, Stergios, "Conflict Without Misperception or Incomplete Information: How the Future Matters," Journal of Conflict Resolution, December 2000, 44(6), 793-807.

Gellner, Ernest, Nations and Nationalism, 1983, Ithaca, NY: Cornell University Press.

Gilpin, Robert, Global Political Economy, 2001, Princeton: Princeton University Press.

Gonzalez, Francisco M., "Poor Protection of Property Rights and the Choice of Technological Backwardness," April 2001, Department of Economics, University of British Columbia.

Greif, Avner, "Self-enforcing Political Systems and Economic Growth: Late Medieval Genoa." in R. Bates, A. Greif, M. Levi, and J-L. Rosenthal,. Analytic Narratives, 1998, Princeton: Princeton University Press.

Greif, Avner, Bates, Robert, and Singh, Smita, "Organizing Violence: Wealth, Power, and Limited Government," presented at the World BankPrinceton Workshop on the Economics of Political Violence, March 2000.

Grossman Herschel I., "Production, Appropriation, and Land Reform," American Economic Review, 1994, 84, 912-921. 
Grossman Herschel I., "Robin Hood and the Redistribution of Property Income," European Journal of Political Economy, September 1995, 11(3), 399-419.

Grossman Herschel I. and Noh, Suk Jae, "Proprietary Public Finance and Economic Welfare," Journal of Public Economics, 1994, 53, 187-204.

Grossman Herschel I. and Kim, Minseong, "Predation and Accumulation," Journal of Economics Growth, September 1996, 1(3), 333-351.

Grossman, Sanford and Hart, Oliver, "The Costs and Benefits of Ownership: A Theory of Vertical and Lateral Integration," Journal of Political Economy, 1986, 84, 691-719.

Haavelmo, Trygve, A Theory of Economic Evolution, 1954, Amsterdam: North-Holland.

Hayek, Friedrich, The Constitution of Liberty, 1960, Chicago: University of Chicago Press.

Hess, Gregory D. and Orphanides, Athanasios, "War and Democracy," Journal of Political Economy, August 2001, 109(4), 776-810.

Hess, Gregory D. and Pelz, Eduard, "The Welfare Costs of Conflict," January 2002.

Hirshleifer, Jack, "The Analytics of Continuing Conflict," Synthese, August 1988, 76, 201-33.

Hirshleifer, Jack, "Conflict and Rent-Seeking Success Functions: Ratio vs Difference Models of Relative Success," Public Choice, November 1989, 63(2), 101-112.

Hirshleifer, Jack, "Anarchy and its Breakdown," Journal of Political Economy, February 1995, 103, 26-52.

Hirshleifer, Jack, The Dark Side of the Force, 2001, New York: Cambridge University Press.

Hirshleifer, Jack and Osborne, Evan, "Truth, Effost, and the Legal Battle," Public Choice, July 2001, 108(1-2), 169-195.

Horowitz, Andrew W., "Time Paths of Land Reform: A Theoretical Model of Reform Dynamics," American Economic Review, September 1993, 1003-1010.

Johnson, Ronald N. and Libecap, Gary, The Federal Civil Service System and the Problem of Bureaucracy, 1994, Chicago: University of Chicago Press.

Keynes, John Maynard, The General Theory of Employment, Interest, and Money, 1964 [1936], New York: Harcourt Brace Jovanovich.

Klebnikov, Paul, Godfather of the Kremlin: The Decline of Russia in the Age of Gangster Capitalism, 2000, New York: Harcourt Inc. 
Konrad, Kai A., "Dynamic Extortion Rents and Contests for Power," January 1999, Department of Economics, Free University of Berlin.

Konrad, Kai A. and Skaperdas, Stergios, "The Market for Protection and the Origin of the State," May 1999, CEPR working paper.

Lee, Jaewoo and Skaperdas, Stergios, "Workshops or Barracks? Productive versus Enforcive Investment and Economic Performance," in M.R. Baye (ed.), Advances in Applied Micoreconomics, 1998, Stamford, CT: JAI Press.

Lucas, Robert E., Models of Business Cycles, Oxford, UK: Basil Blackwell.

Mann, Michael, The Sources of Social Power, volume I: A history of Power from the beginning to A.D. 1760, 1987, New York: Cambirdge University Press.

Marcouiller, Douglas and Young, Leslie, "The Black Hole of Graft: The Predatory State and the Informal Economy," American Economic Review, June 1995, 630-46.

Marselian, Boghos Paul, Essays on Economic Institutions and Transaction Activities in the Macroeconomy, 1998, Ph.D. Dissertation, Department of Economics, University of California, Irvine.

Mazower, Mark, Dark Continent: Europe's Twentieth Century, 1998, New York: Vintage Books.

Mehlum Halvor, Moene, Karl and Torvik, Ragnar "Predator or Prey? Parasitic Enterprises in Economics Development," October, 2000, Department of Economics, University of Oslo.

McGuire, Martin and Olson, Mancur, "The Economics of Autocracy and Majority Rule: The Invisible Hand and the Use of Force," Journal of Economic Literature, March 1996, 34, 72-96.

Milgrom, Paul, "Employment Contracts, Influence Activities, and Efficient Organization Design," Journal of Political Economy, February 1988, 96, 42-60.

Milgrom, Paul and Roberts, John, "The Efficiency of Equity in Organizational Decision Processes," American Economic Review, May 1990, 154-159.

Moselle, Boaz and Polak, Ben, "A Model of a Predatory State," Journal of Law, Economics, and Organization, April 2001, 1-33.

Mueller, Holger and Warneryd, Karl, "Inside Versus Outside Ownership: A Political Theory of the Firm," RAND Journal of Economics, Fall 2001, 32(3), 527-541.

Muthoo, Abhinay, "One the Foundations of Basic Property Rights, Part I: A Model of the State-of-Nature With Two Players," January 2000, University 
of Essex.

Neary, Hugh, "Equilibrium Structure in an Economic Model of Conflict," Economic Inquiry, July 1997, 35, 480-94.

North, Douglass C., Institutions, Institutional Change and Economic Performance, 1990, New York: Cambridge Unviersity Press.

North, Douglass C. And Thomas, Robert P., The Rise of the Western World; A New Economic History, 1973, Cambridge, UK: Cambridge University Press.

North, Douglass C. and Weingast, Barry, "Constitutions and Commitment: The Evolution of Institutions Governing Public Choice in SeventeenthCentury England," Journal of Economic History, December 1989.

Olson, Mancur, "Autocracy, Democracy, and Prosperity," in R.J. Zekhauser (ed.), Strategy and Choice, pp. 131-157, 1991, Cambridge, MA: MIT Press.

Olson, Mancur, "Big Bills Left on the Sidewalk: Why Some Countries are Rich and Others Poor," Journal of Economic Perspectives, 1996, 10, 3-24.

Olson, Mancur, Power and Prosperity: Outgrowing Communist and Capitalist Dictatorships, 2000, New York: Basic Books.

Putnam, Robert D., Bowling Alone, 2000, New York: Simon \& Schuster.

Rajan, Raghuram G. and Zingales, Luigi, "The Tyranny of Inequality," Journal of Public Economics, June 2000, 76, 521-558.

Reynal-Querol, Marta, "Ethnicity, Political Systems, and Civil Wars," Journal of Conflict Resolution, February 2002, 46(1), 29-54.

Robinson, James, "When is a State Predatory?," December 1997, Working paper.

Rodrik, Dani, "Where Did All the Growth Go? External Shocks, Social Conflict, and Growth Collapses," January 1998, NBER Working Paper 6350.

Rosendorff, B. Peter, "Choosing Democracy: The Transition in South Africa," Economics and Politics, 2001, 13(1), 1-29.

Rubinstein, Ariel, "Perfect Equilibrium in a Bargaining Model," Econometrica, January 1982, 50, 97-109.

Sambanis, Nicholas "A Review of Recent Advances and Future Directions in the Literature on Civil War," April 2001, World Bank.

Sandler, Todd, "Economic Analysis of Conflict," Journal of Conflict Resolution, December 2000, , 44(6), 723-729.

Schelling, Thomas C., The Strategy of Conflict, 1960, Cambridge, MA: Harvard University Press.

Shleifer, Andrei, and Robert W. Vishny. "A Survey of Corporate Governance." Journal of Finance 52 (1997): 737-783. 
Skaperdas, Stergios, "Cooperation, Conflict, and Power in the Absence of Property Rights," American Economic Review, September 1992, 82(4), 720-739.

Skaperdas, Stergios, "Contest success functions," Economic Theory, 1996, 7: 283-290.

Skaperdas, Stergios and Syropoulos, Constantinos, "Gangs as Primitive States," in G. Fiorentini and S. Peltzman (eds.), The Economics of Organised Crime, 1995, Cambridge, UK: Cambridge University Press.

Skaperdas, Stergios and Syropoulos, Constantinos, "Can the Shadow of the Future Harm Cooperation," Journal of Economic Behavior and Organization, 1996, 29, 355- 372.

Skaperdas, Stergios and Syropoulos, Constantinos, "The Distribution of Income in the Presence of Appropriative Acitivities," Economica, November 1997, 64, 101-117.

Skaperdas, Stergios and Syropoulos, Constantinos, "Guns, Butter, and Openness: On the Relationship Beween Security and Trade," American Economic Review, Papers and Proceedings, May 2001, 91(2): 353-357.

Tilly, Charles, Coercion, Capital, and European States, 1992, Cambridge, MA: Blackwell.

Tirole, Jean, "The Internal Organization of Government," Oxford Economic Papers, 1994, 46, 1-29.

Tullock, Gordon (1980). "Efficient Rent Seeking," in J.M. Buchanan, R.D. Tollison, and G. Tullock (eds), Toward a Theory of the Rent Seeking Society, College Station: Texas A\&M University Press: 355-372.

Usher, Dan, "The Dynastic Cycle and the Stationary State," American Economic Review, December 1989, 79, 1031-43

Wallis, John J. and North, Douglass C., "Measuring the Transaction Sector in the American Economy, 1870-1970," in S.L. Engerman and R.E.Gallman (eds.), Long-Term factors in American Economic Growth, 1986, Chicago: University of Chicago Press.

Warneryd, Karl, "Distributional Conflict and Jurisdictional Organization," Journal of Public Economics, September 1998, 69(3), 435-450.

Weber, Max, "Bureaucracy," Ch. IX in Economy and Society, 1978, Berkeley, CA: University of California Press.

Wintrobe, Ronald, The Political Economy of Dictatorship, 1998, New York: Cambridge University Press.

Wilson, James Q., Bureaucracy, 1989, New York: Basic Books. 
Zak, Paul J., "Institutions, Property Rights and Growth," 1995, Claremont Graduate School Department of Economics.

Zambrano, Eduardo, "Formal Models of Authority: Introduction and Political Economy Implications," Rationality and Society, 1999, 11(2), 115138. 